\title{
KEY SUB-DISCIPLINES AND METHODS OF TECHNOLOGY PLANNING IN DYNAMIC ENVIRONMENTS
}

\author{
Marek Jemala, Ĺubomír Jemala*
}

"In a world that is changing really quickly, the only strategy that is guaranteed to fail is not taking risks."

Mark Zuckerberg

\section{Introduction}

In a dynamic technology environment, we can identify several major driving forces affecting the formulation and changes of technology plans. First, there is a higher customer demand for products and services resulting from improved availability and a wider assortment of global competition. This determinant is also connected to the strong development of logistics and ICT, but also to the overall globalisation of business. The acceleration of product innovation over the last 20 years has also brought higher requirements on technology plans (Rycroft, 2006). There are higher requirements for product quality, safety and environmental friendliness, which greatly affects technologies and delivery of products to customers. Then, there are higher requirements of owners or shareholders on return on technology investment, arising from the growing global investment opportunities, but also due to the growth in uncertainties and risks in the business environment. Stricter legislation in all areas of business and public interests is an important determinant for technology planning as well. In a synergy, these main factors create the need to innovate business processes more complexly and very flexibly, but especially S\&T (science and technology) or production processes, which greatly affect competitive positions. $R \& D$ project time in many companies is half that 10 years ago. These general drivers for the formulation of technology plans can be regarded as objective. The increase in perceived risks in business also has subjective reasons. These are related to certain limited staff capacities, the growing complexity of technology tasks, the higher personal flexibility required and the necessity for interdisciplinary cooperation in planning (Tan et al., 2009). Thus, technology planning requires the integration of many disciplines: engineering, economics, sociology and psychology (Phaal et al., 2006). Dynamic hyper-competition increases the intensity of product innovation in many areas and usually consequently the need for flexibility

\footnotetext{
* Slovak University of Technology in Bratislava, Institute of Industrial Engineering, Management and Quality (marek.jemala@stuba.sk); Slovak University of Technology in Bratislava, Institute of Management (lubomir. jemala@stuba.sk).
} 
of technological and organisational innovation and their diffusion, which requires continuous learning and cooperation. The so-called Red Queen Effect in this context means that, the continuous development one of the necessary conditions is required in order for any system to survive, due to the parallel dynamics of other systems. These changes require new investment, information, knowledge and other capabilities, which often lead to higher labor mobility and multisourcing, the use of various forms of flexible organisational structures and risk capital for $R \& D$, but also the need to improve cooperation with competitors, customers, suppliers, government institutions, etc. This in turn leads to the need for greater complexity of business strategies, interactive connections with innovation and technology strategies, specialisation of enterprises and their units so as to increase efficiency of internal (also technological) processes, but also to protect own know-how.

The article consists of two main parts. The main purpose of the first part is to deal with the specification of the main differences between the three main sub-disciplines of technology planning, namely foresight, technology forecasting and strategic technology planning. A new discipline called future studies is also mentioned. The second part of the article focuses on the characteristics of individual methods of technology planning. The proposed methodology is completed by a bibliometrical analysis of ScienceDirect database (1823-2013) to identify the main trends.

\section{Foresight, technology forecasting and strategic technology planning}

Planning processes have recently moved from developing plans for a certain environment to forming strategies that allow benefiting from changes (Jemala and Svatý, 2010). In response to that, one of the best solutions is to use a mix of planning methods - technology forecasting, foresight and strategic technology planning (Jemala, 2008). If we look at Figure 1, this model enables us to distinguish among these main forms of technology planning (in simplicity). The key principles of foresight are not the same as of technology forecasting or of strategic technology planning. Foresight is more focused on planning how economic, technological or social factors will be unfolding around the business or society in the future (Linstone, 2011). The main goal of technology foresight is to identify priorities for R\&T so as to obtain the best economic and social benefits (Banuls and Salmeron, 2008). Processes of national foresight may also positively affect a national system of innovation (Canongia, 2007). There are two main methodologies of foresight: the quantitative data-based methodology and expert forecasting (Kim et al., 2009), or forward looking analyses and expert projections (Prior et al., 2013). Based on this division, there are two main advantages related to foresight. Foresight helps managers to better understand new emerging trends and risks in the environment (Constanzo, Mackay, 2010), and foresight may lead to organisational adaptive learning and innovation (Sarpong et al., 2013). 


\section{Figure 1}

Simple model of data utilisation in technology planning

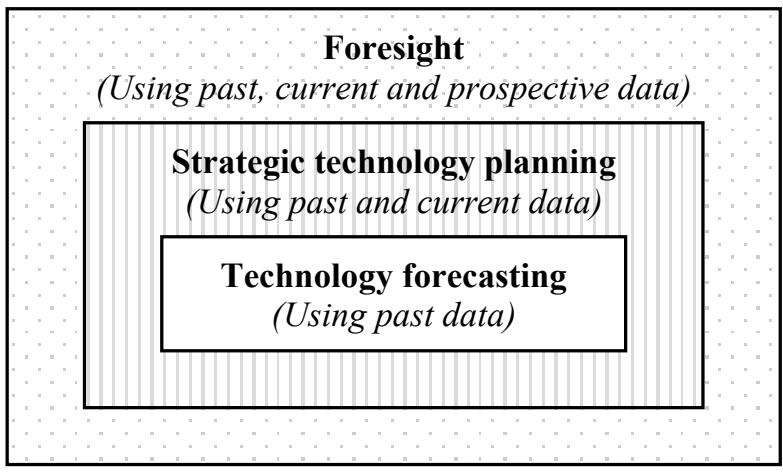

Source: Own design

In contrast, technology forecasters try to predict a highly individual conditioned technology state or figures and the probability of their occurrence at a certain time in the future (e.g., technology parameters, costs, incomes, ROI). Strategic technology planning enables planning of technology future for 1-5 years. Another relevant difference is in data used for planning purposes. Forecasters usually use past data and search for a certain trend that can be extrapolated afterwards. Strategic technology planners use more past and current data that describe the situation and possibilities in the company. These data are used as a key input for further operative planning. Foresight requires more prospective data, which are usually obtained from a broader expert discussion, and creates more synergies of the planning process. Find the balance in planning processes and data applications is always highly individual. Forecasters and planners may take advantage of broader cooperation and may use prospective data in technology planning as well, but this is not usually the case to such an extent as in foresight.

The large diffusion of foresight brings new terms - future studies or future analyses (Kreibich, 2006). The Institute for Future Studies of the EU is one of the main representatives in this context. ${ }^{1}$ Generally, future studies encompass multiple aspects of long-term planning from intra, inter, multi to transdisciplinary perspectives. Future studies within the technology planning are characterised by more complex analyses of broader than technological issues, such as economic, demographic, political or social trends and risks. However, individual differences of future studies require identifying many other aspects, for example, planned objectives, participation, time horizon, scope, methodology, applied methods or the impact of bounded rationality on planning activities.

1 The main role of the Institute is to perform futures studies, long-term analyses and related planning activities. The key mission is to encourage an open, broad-based public debate both on future threats and opportunities. 
In general, the main input for technology forecasting is hindsight, based on the analysis of past results and trends. Technology forecasting can provide valuable inputs for foresight, so-called insights as a source of anticipated future trends and risks. Foresight, in turn, forms one of the inputs for strategic technology planning, but not only in private companies (Figure 2). It is not sufficient to plan technological and business activities only on the basis of foresight, or just on the basis of forecasting and strategic plans, but instead, it is necessary to use the combination of future studies to create better synergistic benefits of technology planning. Future studies should be followed by adequate implementation processes. In this context, so-called 'gatekeepers' play a significant role; they translate strategic technical information into specific tasks and indicators understandable for their colleagues (Savioz and Blum, 2002).

\section{Figure 2}

\section{Primary differentiation and continuity in selected future studies}
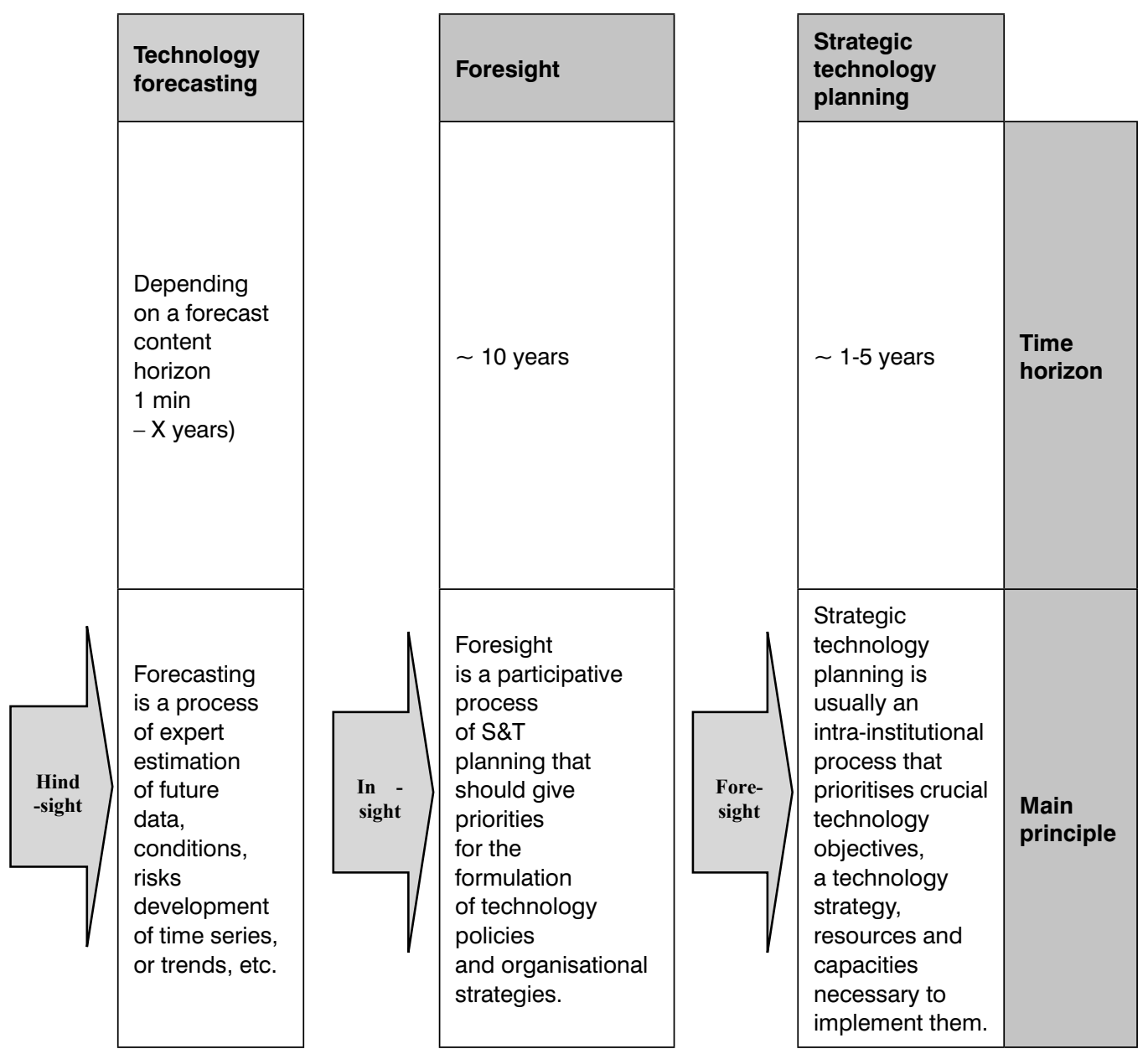


\begin{tabular}{|l|}
\hline \\
Forecasts, \\
prognoses, \\
estimations, \\
trends, risks, \\
etc. \\
\\
\\
\hline Trend \\
extrapolation, \\
S-curve, \\
bliometrical \\
statistics, \\
Expert \\
workshops, \\
Modelling, \\
Econometric \\
techniques, \\
Patent \\
analysis, \\
Diffusion \\
model, \\
Relevance \\
tree, Chaos \\
theory, \\
Contingency \\
theory, etc. \\
\hline \\
Forecasters, \\
experts, \\
managers, \\
etc. \\
\end{tabular}

\begin{tabular}{|l|}
\hline Policy \\
recommendations, \\
formulated S\&T \\
trends and \\
risks, scenarios, \\
research priorities, \\
key technologies, \\
prognoses, \\
roadmapping \\
plans, etc. \\
\hline Literature \\
surveys, Expert \\
Panels, Variant \\
planning, Trend \\
extrapolation, \\
Workshops, \\
Megatrends \\
analysis, Key \\
technologies, \\
Brainstorming, \\
Delphi, \\
Questionnaires, \\
SWOT, \\
Roadmapping, \\
Writing essays \\
Backcasting, \\
Simulation and \\
modeling, Public \\
discussions, etc. \\
\hline Managers, \\
shareholders, \\
line managers, \\
forecasters, \\
researchers, \\
financiers, \\
technologists, etc. \\
\hline
\end{tabular}

\begin{tabular}{|c|c|}
\hline $\begin{array}{l}\text { Strategic } \\
\text { technology } \\
\text { objectives and } \\
\text { plans, variant } \\
\text { scenarios, } \\
\text { investment } \\
\text { priorities, } \\
\text { identified capital } \\
\text { resources, etc. }\end{array}$ & Outputs \\
\hline $\begin{array}{l}\text { SWOT, PEST, } \\
\text { STEER, } \\
\text { BCG matrix, } \\
\text { Benchmarking, } \\
\text { Morphological } \\
\text { analysis } \\
\text { Porter's 5P } \\
\text { analysis, etc. }\end{array}$ & Methods \\
\hline $\begin{array}{l}\text { Technology } \\
\text { managers, } \\
\text { engineers, line } \\
\text { managers, } \\
\text { financiers, etc. }\end{array}$ & $\begin{array}{l}\text { Partici- } \\
\text { pation in } \\
\text { the main } \\
\text { process }\end{array}$ \\
\hline
\end{tabular}

Source: Own design

One of the main differences between technology forecasting and foresight is in the variety of anticipated values. Forecasting is used to anticipate one or few parameters, generally at a specific time, while foresight aims to consider alternative/multiple futures so as to reach the desired one (Georghiou, 2001). Technology forecasting is focused mainly on narrower $\mathrm{R} \& \mathrm{D}$, innovation, market trends or competition. These forecasts are generally based on the extrapolation of historical trends, S-curve of technology/ product life span, trend curves, bibliometrical analyses or expert workshops (Reger, 2001). Many times, forecasters also use modelling and different econometric techniques. In TM, forecasting should also identify individual assumptions about how technology processes/innovation can be impacted or conditioned. Technology forecasters use: power of collective wisdom (e.g., Delphi, expert opinions), leading indicators (field 
scanning, patent analysis, bibliometrical statistics), trend extrapolation, analogies (technology life curve, diffusion model), structural connections (relevance tree, cross-impact matrix) or casual models (economic supply/demand model, system dynamics model). Chaos or contingency theories can be also very well used in technology forecasting (Yu, 2007). Individual forecasting methods and forms are also combined and used complementary within technology planning (Anderson et al., 2008). The main reason for this combination is to gain more complex perspectives on a given technology (Martin and Daim, 2012).

If we look at the development of technology planning in terms of the particular bibliometrical analysis (Table 1), then we can notice that the most developed sub-discipline of technology planning is just foresight, even from the time perspective. One of the first articles on foresight was entitled 'Long range planning of industrial facilities', and was published in 1969. The author described the positive trend among progressive industrialists, i.e., to plan their technology facilities better. This involved two trends: making plans based on long range projections by applying foresight, and analyzing facilities problems in greater depth and with improved methods (Muther, 1969). One of the first articles on technology forecasting entitled: 'New approaches to technological forecasting - Morphological analysis: An integrative approach' was published in 1970. The author explained that successful technology planning must tackle the problem of technological forecasting (O’Neal, 1970).

\section{Table 1}

Development of technology planning - Number of scientific articles

\begin{tabular}{|l|c|c|c|c|c|}
\hline & -1970 & -1980 & -1990 & -2000 & $\mathbf{- 2 0 1 3}$ \\
\hline Foresight & 10 & 32 & 146 & 317 & 892 \\
\hline Technology forecasting & 0 & 15 & 24 & 41 & 104 \\
\hline Strategic technology planning & 1 & 5 & 15 & 33 & 78 \\
\hline
\end{tabular}

Source: ScienceDirect, 2013.

\section{Taxonomy of key technological planning methods}

This second part of the article is to present selected characteristics of individual methods of technology planning. Most of the methods used in technology planning might be classified as either normative or exploratory; these two types are usually meshed for more complex plans. However, technology planning (TP) also requires a more holistic approach that supports planning of unpredictable technology impacts as well and impacts indirectly related to the technology. One of the solutions to ensure proper assessment of entities of a technological system is to use so called fuzzy logic (Multi criteria intuitive logic) (Ross, 2010). Fuzzy logic is used especially in technology 
assessment. The problem of planning technology entities largely depends on other issues of TP. Among the key problems associated with TP:

A. Demands of TM are exaggerated. A technology plan has to solve too many problems of the company or ensure the achievement of too many unrelated goals.

B. There is no continuity of a technology plan with a corporate strategy and goals.

C. There are no clearly defined criteria for TP, or different criteria are used by different stakeholders. Stakeholders are wrongly chosen and informed about the technology, the evaluation criteria and the evaluation process.

D. The whole planning process is improperly organised; there is no feedback, or too little time to prepare the plan. Problems of the technology are limited in time and the technology plan does not fit in this interval.

E. Principal causal dependencies (in terms of technology innovation effects at some time) are no longer up-to-date (Ludwig, 1998).

F. Too many people taking part in the final decision about the technology; etc.

If we look at the development of technology planning methods based on the bibliometrical analysis (Table 2), then we can notice that the most applied methods are modelling and simulation, scenario writing, and interviews. From the time perspective, the most applied methods are forecasting, historical analogy, and modelling and simulation. Many methods have become applied more extensively only after the year 2000, which can be linked to higher perceived risks of the global environment by many institutions. One of the first articles on Technology modelling/planning entitled: 'Computer applications in state planning' was published in 1968. The author described the U.S. Statewide Planning Program based on the uses of computers to compile, tabulate, manipulate, and forecast data. (Varin, 1968)

\section{Table 2}

Development of key technology planning methods - Number of scientific articles ${ }^{2}$

\begin{tabular}{|l|c|c|c|c|c|}
\hline Methods & $\mathbf{- 1 9 7 0}$ & $\mathbf{- 1 9 8 0}$ & $\mathbf{- 1 9 9 0}$ & $\mathbf{- 2 0 0 0}$ & $\mathbf{- 2 0 1 3}$ \\
\hline Modelling a simulation & 4 & 57 & 396 & 1925 & 8800 \\
\hline Scenario writing & 1 & 29 & 152 & 614 & 3932 \\
\hline Interview & 0 & 8 & 81 & 284 & 1605 \\
\hline Questionnaire & 0 & 13 & 78 & 293 & 1589 \\
\hline Key technologies & 0 & 0 & 27 & 199 & 1038 \\
\hline
\end{tabular}

2 Table 2 was compiled based on the bibliometrical analysis; the numbers shown refer to the numbers of scientific articles published in refereed scientific journals and books registered in the ScienceDirect database. 


\begin{tabular}{|c|c|c|c|c|c|}
\hline Workshop & 2 & 25 & 163 & 434 & 950 \\
\hline Forecast & 7 & 59 & 151 & 312 & 851 \\
\hline Regression analysis & 0 & 6 & 33 & 104 & 501 \\
\hline Essays writing & 0 & 8 & 37 & 116 & 279 \\
\hline Historical analogy & 5 & 11 & 25 & 89 & 274 \\
\hline Benchmarking & 0 & 1 & 4 & 34 & 241 \\
\hline Extrapolation & 1 & 13 & 39 & 89 & 235 \\
\hline Delphi & 4 & 13 & 22 & 63 & 193 \\
\hline Diffusion model & 0 & 0 & 4 & 27 & 145 \\
\hline Voting & 0 & 1 & 7 & 23 & 94 \\
\hline Literature survey & 0 & 1 & 5 & 14 & 93 \\
\hline Patent analysis & 0 & 0 & 0 & 2 & 90 \\
\hline Bibliometrical analysis & 0 & 0 & 4 & 19 & 73 \\
\hline Petri-Nets & 0 & 0 & 3 & 16 & 71 \\
\hline Roadmapping & 0 & 0 & 0 & 1 & 68 \\
\hline Analytical hierarchy process & 0 & 0 & 1 & 7 & 59 \\
\hline Expert panel & 0 & 1 & 2 & 15 & 57 \\
\hline Multi-criteria analysis & 0 & 0 & 0 & 10 & 57 \\
\hline S-curve analysis & 0 & 0 & 2 & 12 & 54 \\
\hline SWOT analysis & 0 & 0 & 0 & 4 & 48 \\
\hline Econometrics & 0 & 2 & 5 & 10 & 43 \\
\hline Morphological analysis & 1 & 1 & 6 & 11 & 42 \\
\hline Brainstorming & 0 & 0 & 2 & 11 & 36 \\
\hline Utility analysis & 0 & 0 & 0 & 7 & 33 \\
\hline Contingency theory & 0 & 1 & 3 & 9 & 27 \\
\hline Think tank & 0 & 2 & 2 & 7 & 18 \\
\hline Backcasting & 0 & 0 & 0 & 1 & 17 \\
\hline Chaos theory & 0 & 0 & 0 & 7 & 17 \\
\hline Field scanning & 0 & 0 & 1 & 5 & 15 \\
\hline Cross-impact analysis & 0 & 2 & 3 & 4 & 11 \\
\hline
\end{tabular}

Source: ScienceDirect, 2013.

Individual forms of TP require the use of a combination of individual analytical, assessment and planning methods, which depend on the type of technology, its complexity, scope of TP, time interval, availability of information, as well as individual requirements on TP (a budget, legislative rules, method of technology acquisition, etc.). 
In order to select the most appropriate methods for TP, it is necessary to subdivide these identified methods based on several aspects:

A. In terms of various TP stages - analytical, assessment, and prognostic methods,

B. In terms of a TP organisation process - formal and informal methods,

C. In terms of number of participating actors - individual and collective methods,

D. In terms of applied data - qualitative and quantitative methods,

E. In terms of required knowledge - expert and non-expert methods; etc.

Based on Table 3, we can identify that the most applied methods in TP can be more analytical, formal, individual, qualitative, and expert methods. We can also notice that technology planning is currently strongly conditioned by external and internal analyses; it has a more internal formal nature, more numerical data are used, which are subsequently assessed by experts. This finding is of course determined by the individual characteristics of a technology, company, industry, region, etc.

\section{Table 3}

\section{Taxonomy of key technological planning methods ${ }^{3}$}

\begin{tabular}{|c|c|c|c|c|c|c|c|c|c|c|c|}
\hline Methods & 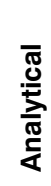 & 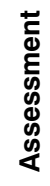 & 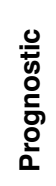 & $\begin{array}{l}\overline{\text { gू }} \\
\text { है유 }\end{array}$ & $\begin{array}{l}\overline{\text { ฐू }} \\
\text { 흘 }\end{array}$ & 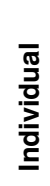 & $\begin{array}{l}\stackrel{0}{0} \\
\stackrel{\Xi}{\mathrm{d}} \\
\overline{0}\end{array}$ & 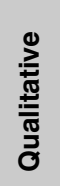 & 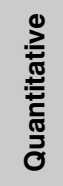 & $\begin{array}{l}\frac{T}{\Phi} \\
\frac{0}{x} \\
\text { ய }\end{array}$ & 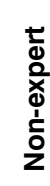 \\
\hline Modelling and simulation & $\mathbf{x}^{*}$ & $\mathbf{x}$ & $\mathbf{x}$ & $\mathbf{x}$ & & $\mathbf{x}$ & & & $\mathbf{x}$ & $\mathbf{x}$ & \\
\hline Scenario writing & $\mathbf{x}$ & & $x$ & $\mathbf{x}$ & & & $\mathbf{x}$ & $x$ & & $x$ & \\
\hline Interview & $\mathbf{x}$ & $\mathbf{x}$ & & $\mathbf{x}$ & $\mathbf{x}$ & & $\mathbf{x}$ & $\mathbf{x}$ & & $\mathbf{x}$ & \\
\hline Questionnaire & $\mathbf{x}$ & $\mathbf{x}$ & & $\mathbf{x}$ & & $\mathbf{x}$ & & & $\mathbf{x}$ & $\mathbf{x}$ & $\mathbf{x}$ \\
\hline Key technologies & $\mathbf{x}$ & $\mathbf{x}$ & $\mathbf{x}$ & $\mathbf{x}$ & & & $\mathbf{x}$ & $\mathbf{x}$ & & $x$ & $\mathbf{x}$ \\
\hline Workshop & & $x$ & $\mathbf{x}$ & $\mathbf{x}$ & & & $\mathbf{x}$ & $x$ & & $x$ & \\
\hline Forecast & & & $x$ & $x$ & & $\mathbf{x}$ & & $x$ & $\mathbf{x}$ & $x$ & \\
\hline Regression analysis & $\mathbf{x}$ & $\mathbf{x}$ & $\mathbf{x}$ & $\mathbf{x}$ & & $\mathbf{x}$ & & & $\mathbf{x}$ & $\mathbf{x}$ & \\
\hline Essays writing & & $\mathbf{x}$ & $\mathbf{x}$ & & $\mathbf{x}$ & $\mathbf{x}$ & & $\mathbf{x}$ & & $\mathbf{x}$ & $\mathbf{x}$ \\
\hline Historical analogy & $\mathbf{x}$ & $\mathbf{x}$ & $\mathbf{x}$ & $\mathbf{x}$ & & $x$ & & $x$ & & $x$ & \\
\hline Benchmarking & $\mathrm{x}$ & $x$ & & $\mathrm{x}$ & & $\mathrm{x}$ & & & $\mathrm{x}$ & $\mathrm{x}$ & \\
\hline
\end{tabular}

3 Table 3 was prepared on the basis of an extensive review of primary characteristics of the most common methods used in TP. It is not the purpose of this study to characterise specific features and further differences among these methods, which are to a great extent dependent on their individual applications. The text only mentions some interesting characteristics of the selected methods. 


\begin{tabular}{|c|c|c|c|c|c|c|c|c|c|c|c|}
\hline Extrapolation & $x$ & $x$ & $x$ & $x$ & & $x$ & & $x$ & & $\mathrm{x}$ & \\
\hline Delphi & $\mathrm{x}$ & $\mathrm{x}$ & $x$ & $x$ & & & $x$ & $x$ & $x$ & $x$ & \\
\hline Diffusion model & $x$ & $x$ & $x$ & $x$ & & $x$ & & & $x$ & $X$ & \\
\hline Voting & $x$ & $x$ & & $x$ & & & $x$ & & $x$ & & $x$ \\
\hline Literature survey & $x$ & $x$ & & $x$ & & $x$ & & $x$ & & $x$ & \\
\hline Patent analysis & $\mathrm{x}$ & $x$ & $\mathrm{x}$ & $x$ & & $x$ & & & $x$ & $\mathrm{X}$ & \\
\hline Bibliometrical analysis & $x$ & $x$ & $x$ & $x$ & & $x$ & & & $x$ & $x$ & \\
\hline Petri-Nets & $x$ & $x$ & $x$ & $x$ & & & $x$ & $x$ & & $X$ & \\
\hline Roadmapping & $x$ & $x$ & $x$ & $x$ & & & $x$ & $x$ & & $x$ & \\
\hline $\begin{array}{l}\text { Analytical hierarchy } \\
\text { process }\end{array}$ & $x$ & $\mathrm{x}$ & & $\mathrm{x}$ & & & $x$ & & $\mathrm{x}$ & $\mathrm{X}$ & \\
\hline Expert panel & $x$ & $x$ & $x$ & $x$ & & & $x$ & $x$ & & $x$ & \\
\hline Multi-criteria analysis & $x$ & $x$ & & $x$ & & $x$ & & & $x$ & $x$ & \\
\hline S-curve analysis & $x$ & $x$ & $x$ & $x$ & & $x$ & & & $x$ & $x$ & \\
\hline SWOT analysis & $x$ & $x$ & & $x$ & & $x$ & & $x$ & & $x$ & \\
\hline Econometrics & $x$ & $x$ & $x$ & $x$ & & $x$ & & & $x$ & $\mathrm{x}$ & \\
\hline Morphological analysis & $x$ & $x$ & & $x$ & & $x$ & & & $x$ & $x$ & \\
\hline Brainstorming & $x$ & $x$ & $x$ & & $x$ & & $x$ & $x$ & & & $x$ \\
\hline Utility analysis & $x$ & $x$ & $x$ & $x$ & & $x$ & & & $x$ & $x$ & \\
\hline Contingency theory & $x$ & $x$ & $x$ & $\mathrm{x}$ & & $x$ & & $x$ & & $x$ & \\
\hline Think tank & $x$ & $x$ & $x$ & $x$ & & & $x$ & $x$ & & $x$ & \\
\hline Backcasting & $x$ & $x$ & $x$ & $x$ & & & $x$ & $x$ & & $\mathrm{x}$ & \\
\hline Chaos theory & $x$ & $x$ & $x$ & $x$ & & $x$ & & $x$ & & $x$ & \\
\hline Field scanning & $x$ & $x$ & & $x$ & & $x$ & & $x$ & & $x$ & \\
\hline Cross-impact analysis & $\mathrm{x}$ & $\mathrm{x}$ & $\mathrm{x}$ & $\mathrm{x}$ & & & $\mathrm{x}$ & & $\mathrm{x}$ & $\mathrm{x}$ & \\
\hline
\end{tabular}

* The size of the letter $X$ in the table represents a preference for inclusion in the group (in ascending order).

Source: Own design

Qualitative methods such as interview, questionnaire and historical analogy are applied more extensively because of the inability to quantify many soft and human elements, but especially connections within a technological system. These characteristics must be specified verbally and after determining the evaluation criteria, it is possible to quantify them. Collective methods of TP such as brainstorming, Delphi, synectics and different workshops are mostly used in the first phase of TP in order to determine broader and more complex technology features and determinants and these methods usually precede closer or individual expert panels. For example, synectics is similar to brainstorming, in order to stimulate thought processes of a wider group of people. This process is based on the collective assessment of a technology, recording of the process (audio, 
video), the partial analysis of negotiation results, and experimenting with alternative methods of solving problems for the greater success of the process. This method requires inducing creative behaviour to reduce inhibitions and to "release" human creativity. The central principle of this method is also specific: "Trust in things that you feel alien and disagree with things that are confidential to you." The method encourages the search for unusual solutions and impacts of the technology, mainly based on analogies. Synectics is a more challenging method for an application as Brainstorming, because the process is more complex and requires more efforts and time. It is also a more beneficial method, because the final result is more specified to a particular conclusion, not only in a draft form. For example, Microsoft Corporation uses synectics in recognition of own technology expertise in the design and development of technology solutions in own environments. As a part of IBM PartnerWorld, synectics enables leveraging of valuable benefits, tools and enhance the client support, etc. (IBM, 2013).

The analytical hierarchy process is usually used to prioritise technology-based research programmes. The most common criteria include the possibility to create a new market, market needs, policy fitness, strategic goals fitness, and the size of a future market (Kim et al., 2009). Planning cells are formal expert analytical and forecasting methods. Planning cells are based on the cooperation of 15-25 people from different backgrounds who collectively solve an identified problem (a technology plan) within a specified time. The process is accompanied by two moderators (e.g., one man, one woman). The whole process takes 4-6 days. There are a few main rules: it is necessary to determine in advance what information will be relevant for the assessment and planning, and in what time; information should have an expert credibility; different methods of presentation must be used (audio, video); participants are financially rewarded and spend a few days together in a cell (4-5 persons). At the end of the process, several variants for a given problem are formulated (Dienel, 2002). For example, NASA uses planning cells as part of its distributed technology planning that complements the traditional hierarchical technology planning. The whole process is based on multiple agents developing portions of a joint technology plan independently. Roles of agents are fixed, or constrained by capabilities and experience. Each agent regularly communicates planning decisions (effects, resources, etc.) to other agents at planning time. The whole process is coordinated by TM (Clement and Decker, 2005).

For example, Petri-nets (network elements and links, e.g., a technological system) is a method of mathematical modelling for the description of discrete distributed systems, which are also technologies. A Petri-net is a bipartite graph of a technological system, in which nodes represent transitions (activities/links, differentiated by vertical lines), points mean conditions (differentiated by circles) and curves describing places (differentiated by arrows). A Petri-net provides graphical records of gradual technological processes involving selection, repetition and parallel implementation. A Petri-net has a precise mathematical definition of its semantics, with good mathematical theory for process analyses; therefore, it has a good visual value for TP (Desel and Juhás, 2001), similarly to roadmapping. The main disadvantage of the Petri-net is the need to understand the exact semantics of this method.

Technology roadmapping is especially useful when planning large-scale long-term technology-push R\&D projects (Wancura et al., 2013). In this case, however, roadmapping 
can significantly increase TM costs (Lee et al., 2007). Roadmapping provides a method to prepare a variant technology strategy (Gerdsri and Kocaoglu, 2007), by describing the paths to be followed so as to integrate technologies with products and markets (Caetano and Amaral, 2011). For example, Steve Jobs managed to define Apple's roadmap for the next several years. Jobs was overseeing the development of the iCloud project and masterminding updated versions of the iPod, iPad, iPhone and MacBooks, ensuring that at least 4 years' worth of products are in the pipeline (Shilov, 2011).

\section{Conclusions}

The value of a technology in a company depends not only on its purposeful and effective configuration and contribution to the formation of VA, but also on other synergies whether within or outside this company. One of the key decisions in TM is to define the degree of uniqueness of technological activities, which primarily affects technology planning and, consequently, technology investments and their long-term capitalisation. However, development, applications and protection of unique technologies should not bring only a unique competitive advantage, but also the ability to better adapt to subsequent changes in the business environment resulting from the reactions of competitors. A key factor in maintaining and improving a competitive advantage of many companies is always practical and efficient innovation. This, however, does not only depend on available investment and new management plans, but also on dynamic technological capabilities, diversification of production, and positive technological heritage of the company that affect other capacities of the company, but also its goodwill. Increasingly important are also political impacts on business, designed to meet policy goals and related investments in technology or technology transfer. Governments that support domestic R\&D, product and technological innovation, may create long-term innovation and business capacities, including the longer-term support for employment. For example, these are countries like USA, Japan, Germany, Finland, Denmark or modern global leaders China and India.

If we look at the development of technology planning in terms of the particular bibliometrical analysis, then we can notice that the most developed sub-discipline of technology planning is participative technology planning, later called foresight, even from the time perspective. If we look at the development of technology planning methods, then we can see that the most applied methods are modelling and simulation, scenario writing, and interviews. From the time perspective, the most applied methods are forecasting, historical analogy, and modelling and simulation. Many methods currently used in technology planning reflect the higher demands on management of technology resulting from business turbulences, but also from the changes in technology, society and the environment.

\section{References}

ANDERSON, T. R.; DAIM, T. U.; KIM, J. Technology forecasting for wireless communication. Technovation. 2008, vol. 28 , no. 4 , s. $602-614$.

BANULS, V. A.; SALMER, J. L. Foresighting key areas in the information technology industry. Technovation. 2008 , vol. 28 , no. 1 , s. 103-111. 
CAETANO, M.; AMARAL, D. C. Roadmapping for technology push and partnership: A contribution for open innovation environments. Technovation. 2011, vol. 31, no. 3, s. 320-335.

CANONGIA, C. Synergy between competitive intelligence (Cl), knowledge management (KM) and technology foresight (TF) as a strategic model of prospecting - The use of biotechnology in the development of drugs against breast cancer. Biotechnology advances. 2007, vol. 25, no. 1, s. 57-74.

CLEMENT, B.; DECKER, K. Multiagent Planning: A Survey of Research and Applications, NASA [online]. 2005 [cit. 2005-03-15]. http://ai.jpl.nasa.gov/public/home/bclement/papers/ma_planning_ aaai05_presented.pdf.

CONSTANZO, L.; MACKAY, R. B. Handbook of research on strategy and foresight. Cheltenham : Edward Elgar, 2010. 548 s. ISBN 184542963X.

DESEL, J.; JUHÁS, G. Lecture Notes in Computer Science. Berlin/Heidelberg: Springer, 2001. 450 s. ISBN 978-3-540-43067-4.

DIENEL, P. C. Die Planungszelle. Der Bürger als Chance. Opladen : Westdeutscher Verlag, 2002. 295 s. ISBN 3531330284.

GEORGHIOU, L. Third generation foresight: integrating the socio-economic dimension. Prednáška na konferencii The International Conference on Technology Foresight - the Approach to and Potential for New Technology Foresight, Tokyo, 2001.

GERDSRI, N.; KOCAOGLU, D. F. Applying the Analytical Hierarchy Process (AHP) to build a strategic framework for technology roadmapping. Mathematical and Computer Modelling. 2007, vol. 46, no. 7-8, s. 1071-1080.

IBM, PartnerWorld program, IBM [online]. 2013 [cit. 2013-05-15]. www-304.ibm.com/partnerworld/ wps/servlet/ContentHandler/pw_com_pwp_index.

JEMALA, M.; SVATÝ, F. Ontológia foresightu: Podnety pre tvorbu vízie SR na báze metodiky foresightu. Bratislava : Ekonóm, 2010. 154 s. ISBN 978-80-225-2879-5.

JEMALA, L. Podnikatel'ský manažment a marketing. Bratislava : Vydavatel'stvo STU, 2008, s. 65-77. ISBN 978-80-227-2860-7.

KIM, CH.; KIM, H.; HAN, S. H.; KIM, CH.; KIM, M. K.; PARK, S. H. Developing a technology roadmap for construction R\&D through interdisciplinary research efforts. Automation in Constructions. 2009, vol. 18 , no. 3, s. 330-337.

$\mathrm{KREIBICH}, \mathrm{R}$. Arbeitsbericht Nr. 23: Zukunftsforschung [Working Paper]. Berlin : Institute for Futures Studies and Technology Assessment, 2006. Institut für Zukunftsstudien und Technologiebewertung. www.izt.de/fileadmin/downloads/pdf/IZT_AB23.pdf.

LEE, S.; KANG, S.; PARK, Y.; PARK. Y. Technology roadmapping for R\&D planning: The case of the Korean parts and materials industry. Technovation. 2007, vol. 27, no. 5, s. 433-445.

LINSTONE, H. A. Three eras of technology foresight. Technovation. 2011, vol. 31, no. 1, s. 69-76.

LUDWIG, B. Fuzzy logic applications in technology assessment studies. Journal of Intelligent and Fuzzy Systems. 1998, vol. 1, no. 6, s. 375-388.

MARTIN, H.; DAIM, T. U. Technology roadmap development process (TRDP) for the service sector: A conceptual framework. Technology in Society. 2012, vol. 34, no. 2, s. 94-105.

MUTHER, R. Long range planning of industrial facilities. Long Range Planning. 1969, vol. 2, no. 2, s. 58-60.

O'NEAL, R. CH. New approaches to technological forecasting - Morphological analysis: An integrative approach. Business Horizons. 1970, vol. 13, no. 6, s. 47-58.

PHAAL, R.; FARRUKH, C. J. P.; PROBERT, D. R. Technology management tools: concept, development and application. Technovation. 2006, vol. 26, no. 3, s. 336-344.

PRIOR, T.; DALY, J.; MASON, L.; GIURCO, D. Resourcing the future: Using foresight in resource governance. Geoforum. 2013, vol. 44, no. 3, s. 316-328.

REGER, G. Technology foresight in companies: from an indicator to a network and process perspective. Technology Analysis \& Strategic Management. 2001, vol. 13, no. 4, s. 533-553.

ROSS, T. J. Fuzzy Logic with Engineering Applications. Chichester : Wiley-Blackwell, 2010. 606 s. ISBN 047074376X. 
RYCROFT, R. W. Time and technological innovation: Implications for public policy. Technology in Society. 2006, vol. 28, no. 3, s. 281-301.

SARPONG, D.; MACLEAN, M.; DAVIES, C. A matter of foresight: How practices enable (or impede) organizational foresightfulness. European Management Journal. 2013, vol. 31, no. 6, s. 1-12.

SAVIOZ, P.; BLUM, M. Strategic forecast tool for SMEs: how the opportunity landscape interacts with business strategy to anticipate technological trends. Technovation. 2002, vol. 22, no. 1, s. 91-100.

SCIENCEDIRECT, Search, ScienceDirect [online]. 2013 [cit. 2013-06-17]. www.sciencedirect.com/ science?_ob $=$ MiamiSearchURL\&_method $=$ requestForm\&_btn $=Y \&$ zone $=$ TopNavBar\&_origin $=$ home $_{-}$_acct $=$C000051056\&_version $=1$ \&_urlVersion $^{-}=1$ \&_userid $^{-} 1052399 \& \mathrm{md} 5=6 \mathrm{~d}$ 0d8f5406684e929845851f33b1a05c.

SHILOV, A. Apple Has Set Roadmap for Several Years - Report. Steve Jobs Defined Apple's Roadmap for Several Years to Come, XBITLABS [online]. 2011 [cit. 2011-07-17]. www.xbitlabs.com/news/ other/display/20111010134622_Apple_Has_Set_Roadmap_for_Several_Years_Report.html.

TAN, J.; FISCHER, E.; MITCHELL, R.; PHAN, P. At the centre of the action: Innovation and technology strategy research in the small business setting. Journal of Small Business Management. 2009, vol. 47 , no. 3, s. 233-262.

VAVRIN, D. W. Computer applications in state planning. Socio-Economic Planning Sciences. 1968, vol. 1 , no. 3, s. 335-344.

WANCURA, H.; MONTIGNAC, F.; MAZZUCCHI, CH.; SPIRIG, M. E.; COSTA, J. B. Creating a solid base for technology road mapping using an integrated technology monitoring and assessment tool. Social and Behavioral Sciences. 2013, vol. 75, no. 3, s. 370-382.

YU, O. Comparison of Technology Forecasting Methods for Multi-National Enterprises: The Case for a Decision- Focused Scenario Approach, In HÖRLESBERGER, M.; EL-NAWAWI, M.; KHALIL, T. (ed.). Challenges in the Management of New Technologies. Miami : World Scientific, 2007, s. 409-424, ISBN 981-270-855-3.

\title{
KEY SUB-DISCIPLINES AND METHODS OF TECHNOLOGY PLANNING IN DYNAMIC ENVIRONMENT
}

\begin{abstract}
The dynamic development in all areas of business brings shorter life cycles of products, technologies, as well as organisational structures and enterprises. The critical factor of many technological changes is not the technology innovation process, but finding a new application for an existing technology (Rycroft, 2006). The form of technology planning depends on the capabilities and requirements of a specific enterprise, but also on external determinants that affect its internal technological capabilities. Within the formulation of a technology strategy (TS), it is necessary that managers adequately incorporate different dimensions and needs of own technology in TS, but also that technology elements are appropriately designed and substitutable. This article has two main goals. The first is to describe methodically the main specific features and forms of technology planning/ TS through a comprehensive study of available professional literature. The second goal is to analyse the development of technology planning methods based on a bibliometrical analysis of ScienceDirect database (1823-2013).
\end{abstract}

Keywords: Integrated technology management, Technology planning, Technology strategy, Foresight, Technology forecasting

JEL Classification: $\mathrm{O} 31, \mathrm{O} 32, \mathrm{O} 33$ 